\title{
Psychological Chess: Erdoğan and the Syrian Refugee Crisis
}

\author{
Janice L. Farkas
}

\section{Introduction}

The mosques are our barracks,
the domes our helmets, the
minarets our bayonets and the faithful our soldiers ..." This quote is identified as the poem read by Recep Tayyip Erdoğan in 1999. The utterance of these words prompted the political figure, the Mayor of Istanbul at that time, to be arrested for inciting religious hated and jailed for four months (Mays, 2017). Erdoğan, now Turkey's elected President, is a controversial figure who has had a long political career, serving as its longest leader and well-known on the world stage. In 2018, he was elected President under a new, constitutionally approved Presidential System of Government after serving in many other governmental roles. Erdoğan's leadership and foreign policies have been the subject of much contention and criticism over the years. The President's governance style has been remarked to be "autocratic" and he has been referred to as a "wolf dressed in a sheep's clothing” (Görener and Ucal 2011).

The society and identity of Turkey is neither Western nor Eastern. Its roots are buried deep within the historical Ottoman Empire and is situated "strategically" as a bridge between Europe's Balkan region, the Middle East nations of Syria, Iran and Iraq, and
Eastern European countries formerly part of the Soviet Union. Since the Syrian civil war began in 2011, Turkey has been subjected to accepting a catastrophic number of Syrian refugees. Nearly four million Syrians crossed into Turkey by mid-2020 (Aljazeerah, 2020). As a result, Turkey has sustained outstanding impacts domestically upon its economy and citizenry. Internationally, Turkey was thrust into controversy with the European Union (EU) and other Western nations (Kirisci 2021).

\section{Need}

7 his paper was developed from a need to reflect upon the political policies of President Recep Erdoğan with regard to the Syrian refugee crisis and resultant domestic and international issues. Any recommendations for action must be made with an understanding of the psychological drivers of the leader and his political motivations and actions. This paper will address the noted actions through a review of relevant literature and studies performed upon the following:

a. A background of the country of Turkey, and President Erdoğan's;

b. A review of the leader's handling of the influx of Syrian citizens; 
c. Theoretical study of psychological motivators and application to President Erdoğan's policy pertaining to the refugee crisis.

d. Theoretical review of the rational actor theory, power motivation and social identity theory; and

e. Recommendations for issue resolution.

\section{Background}

\section{Turkey's Beginning: The Ottoman Empire}

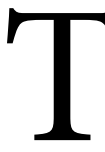

The current nation of Turkey arose from the vestiges of the Ottoman Empire. The First Ottoman Empire came into existence in the form of a religious and financial enterprise. From 1280-1413, the Ottomans began expanding into the Byzantine-held regions of the Balkans and Anatolia, claiming land and riches. While Islamic in nature, the Ottoman Empire developed a system of capturing property and wealth, while allowing the Christian leaders of those regions the ability to maintain leadership through a trade of soldiers and finances to support the Ottoman forces. These forces, known as the Janissary army, were made up of Christian youths from conquered regions, and taught in the ways of Islam, Arabic, and the Ottomans (Shaw 1976).

After a period of political and internal turmoil, the First Ottoman Empire collapsed, and went through a restoration period of rebuilding and resurgence. Campaigns throughout the Balkans, Anatolia and Europe helped re-establish the Ottoman stronghold throughout the empirical region. Wars with Venice, Russia and Safavids allowed the Ottoman Empire to conquer wider regions of territory throughout the Middle East and Europe. By the 1500s, the Empire had expanded well into Europe, toward Russia and into the mid-East regions (see Fig. 1).

These holdings in land and wealth would continue into the late $18^{\text {th }}$ Century, when "the sick man of Europe" began experiencing a loss of its stronghold (Findley 2010). Due to changes within the Empire and "decentralization" of its governance, along with the expansion of European powers, American independence, wars with Russia, and Napoleonic invasion in Egypt, the Ottoman land hold began to diminish. Failed treaties, Janissary rebellions and lost battles weakened the Empire, and permitted regions once held by the Empire be slowly and methodically carved away to a new nation or taken by another European power (Shaw 1976 and Findley 2010).

As the Empire continued to weaken, a series of events occurred that would seal the fate of the Ottomans at the beginning of the $20^{\text {th }}$ Century. World War I, as well as the Young Turks Rebellion, played a large part in the loss of the balance of Ottoman territory and power. As is common with many revolutions, the Young Turks proceeded with an attempt to overthrow and revolt upon a resistance to taxation and corruption in the government of Constantinople, the Ottoman capitol (Zurcher 2019). By this time, Greece 
had already won its independence and Albania, Macedonia, Armenia within the Balkans were forcing constitutional reform within the Empire. This revolution influenced other regions to spark rebellions, along with the Italo-Turkish War just prior to World War I, further spurred on the demise of the Ottomans as a global force (Ahmad 2014).

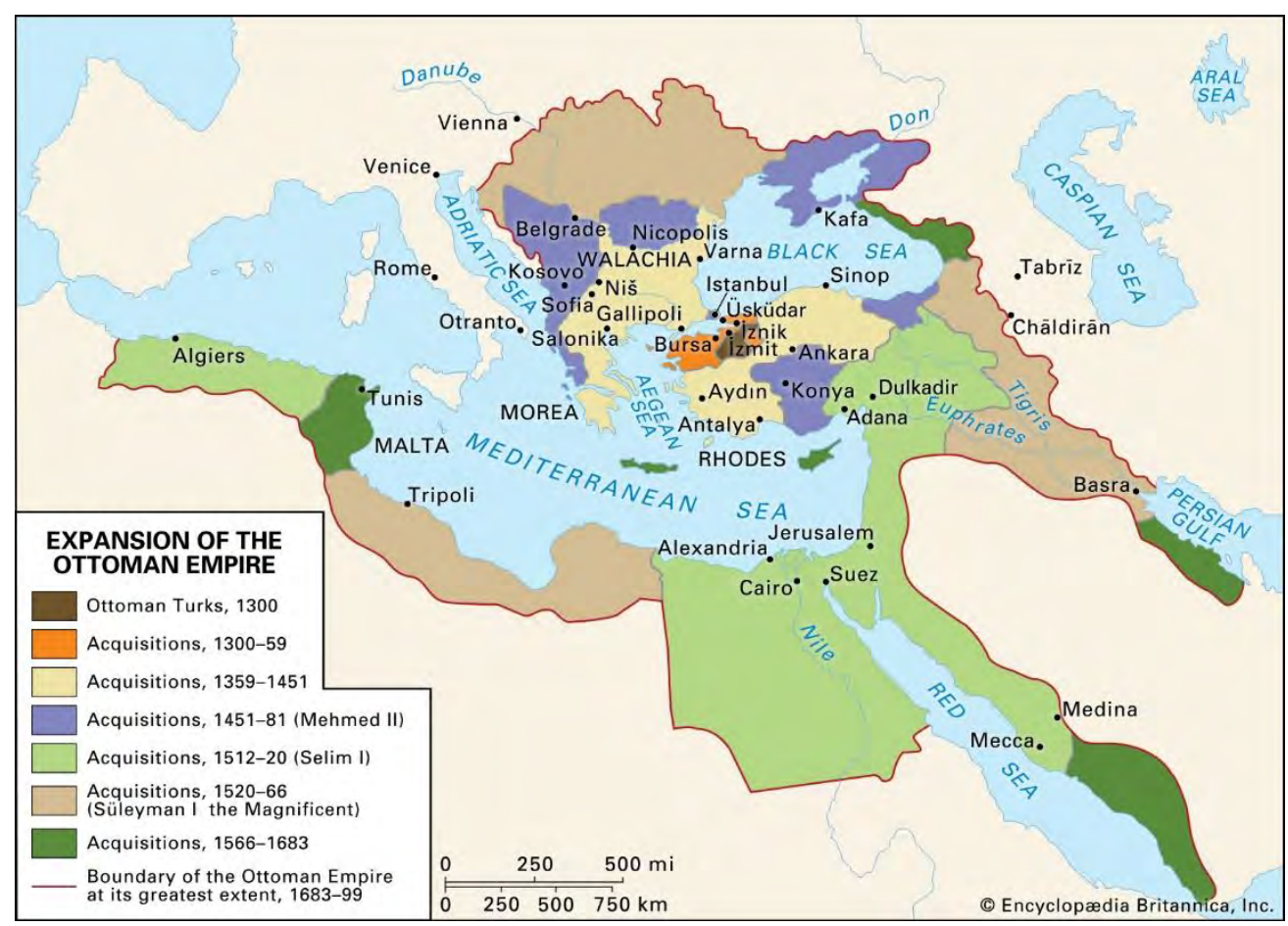

Fig. 1. Map showing the expansion of the Ottoman Empire (c. 1300-1700).

Encyclopedia Britannica, Inc.

As World War I raged, the Ottomans aligned themselves with Germany, who seemed a sure victor. Germany, too, saw the alliance to be profitable in future endeavors. "Ottoman territory could be pivotal to Germany's place in the world, connecting the German and Habsburg realms to the Near East and thus the Persian Gulf and Indian Ocean" (Aksakal, 2008, 65). The Ottomans signed a "secret treaty" with Germany to ally and fight, a choice that would lead to the Empire's final demise. The losses sustained by Germany and the Ottomans were irrefutable and, in 1920, the victors of World War I would enter into an agreement known as the Treaty of Sèvres, wherein the territories held by the Empire were divided and distributed among the war's prevailing nations (Fig. 2).

Despite the replacement of the Treaty of Sèvres by the Treaty of Lausanne in 1923, the division of Ottoman lands remained unchanged, and the land remaining the possession of the Ottoman Empire became what is known 
as Turkey today. The disposition of territories provided separation of Persian lands to the Middle East, Armenia to the east - which had suffered great losses characterized by most as a genocide - and provided land to the Kurds in northern Anatolia (Findley 2010). The losses were great, and it thrust the Ottomans into a period of years-long in- ternal struggle for political and military stability. In 1923, the Sultanate form of leadership within the Empire was abolished due to the "undignified behavior" of the last Sultan, Mehmed VI Vahdettin, who was exiled until his death. A new republic was declared on October 23,1923 , and the nation of Turkey was established (Feroz 1993).

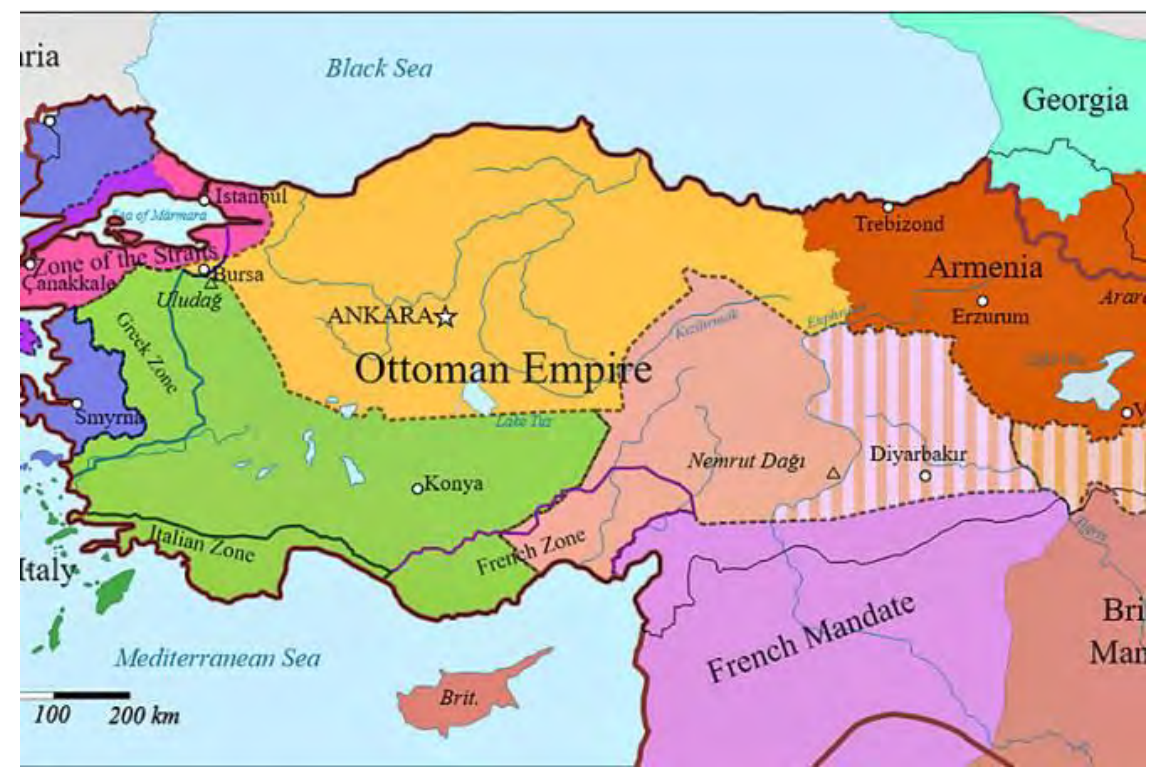

Fig. 2. Map of Treaty of Sèvres. Armenpress.

\section{A Nation in Development}

For the first time in over 600 years, the new republic would function as a national body, no longer ruled as an Islamic Caliphate. The new ruler, Mustafa Kemal, "preferred to create a new ideology and symbols which would permit Turkey to progress rapidly into the twentieth century" (Feroz 1993 56). In the years that followed Turkey's establishment, the government began to refine its diplomatic and foreign policies with European nations. Ankara, the new capital of the nation worked to strengthen ties with Moscow and looked to Italy for diversified relations. This developmental period would continue through to nearly the middle of the century, when the second World War would overtake Europe. By that time, Turkey had begun to identify its culture through a religious lens, replacing sharia code with laws based upon a more Western code (Swiss Italian and German law models), and replacing Arabic as the written language with Latin, rendering a majority of the population 
illiterate (Feroz 1993). Following World War II, a series of political parties controlled the government of Turkey, witnessed a coup détat in 1960, another in 1971, and a third in 1980. The time between the 1960s and 1980s was a politically charged time for Turkey. The Justice Party, Democratic Party, Republican Reliance Party, Welfare Party and the Nationalist Action Party all strove for power at different times of this transition period, while the current leader, Recep Tayyip Erdoğan, was beginning his political career (Feroz 1993).

\section{Recep Tayyip Erdoğan}

Recep Tayyip Erdoğan was born in 1954 in Istanbul, Turkey. After receiving his graduation diploma from Marmara University's Faculty of Economics and Administrative Sciences in 1981, he began a career in politics, which was notably delayed due to the 1980 coup. However, by 1983, the newest political party, the Welfare Party, was established and Erdoğan appointed Beyoğlu District Head (Biography 2021). The Welfare Party, successor to the National Salvation Party, is an Islamist-based organization. "[T]he Welfare Party fit the classic definition of a 'populist' movement as the mobilization of the urban poor by the minority segments of the upper and middle classes into action against the status quo" (Gülalp 2001, 434).

During his initial tenure with the party, Erdoğan touts, in his biography, working to engage women and youth in politics, and bringing awareness of the new party to the Turkish masses. By 1994, Erdoğan was elected Mayor of Istanbul. Focusing upon reforms for critical infrastructure and social issues within the City, as well as financial concerns. In 1997, the leader incited religious discord by reading controversial poetry and was imprisoned, ending his Mayoral term (Mays 2017). Upon release from prison, Erdoğan reestablished his political career and by 2001 saw to the development of the Justice and Development Party (AKP Party), which became the "sole ruling party" of Turkey by 2002 (Biography 2021). In 2003, Erdoğan became the Prime Minister of Turkey, was re-elected in 2007 and 2011 in that parliamentary elections for that position. In 2014, Erdoğan was elected as President of the nation and, in 2018, under a constitutionally amended system, was elected the first President of the Presidential System of Government (Biography 2021).

In between his two most recent elections to power, the President's position was challenged in a July 2016 coup d'état attempt where unknown factions used military forces to storm the capitol of Ankara and city of Istanbul, as well as television stations. It was also declared that a new constitution was being written. Erdoğan, was on vacation at the time and hurried back to Ankara and thwarted the coup attempt overnight (BBC News, 2016). The leader had called upon his supporters to take to the streets and stop the overthrow. The President accused a Muslim cleric, Fethulleh Gülen, self-exiled in the United States, or organizing the coup. Gülen and his supporters in the United States have been tormented and threatened since that time by Erdoğan supporters, 
despite a lack of proof of Gülen's participation in the coup Adely, 2019). The attempt at a coup détat is indicative of a deeper issue within Turkey and the leadership of Erdoğan. It signals a deep cleavage in the nation and has identified the President as an autocratic governor and a pugnacious leader who is quick to argue.

Research has indicated a change in Turkey's foreign policy since President Erdoğan's rise to power and, more notably, since the attempted overthrow in 2016. Specifically, the modified policy underscored a draw toward Russia, deviance from Western powers such as the United States and leading European nations, and a more independent role in affairs in the Middle East (Haugom 2019). The President has exhibited a willingness to extend military operations beyond its national borders and engage in a more "transactional and interest-based" relationship with other nations (Haugom 2019, 211). Additionally, Turkey has deviated from prior policy regarding the $\mathrm{EU}$, making failed plays to join the alliance. Any attempt to join has been opposed, due to questionable human rights treatments of individuals, both home and abroad, by Turkey (BBC News, 2020). One of the most notable interactions with the EU involved the negotiation of an agreement with the Union regarding management and compensation to republic for harboring the Syrian refugees, affirming the "transactional" nature of the country's policies under Erdoğan.

\section{Syrian Refugee Crisis}

Unrest and civil war in neighboring Syria began in or around March of 2011. The conflict plagued the country and, due to the violent and inhumane conditions millions of citizens began to exit the country into neighboring nations. Syria shares its entire northern border with Turkey which resulted in the influx of approximately four million of Syrian's migrants looking for protection and a better life. This emigration into Turkey, however, thrust the country into great societal and economic dilemmas. This predicament forced President Erdoğan to establish policies, including closing its border with Syria and engaging in diplomatic negotiations and, ultimately, to take a hard line with the EU.

At the initial onset of the crisis, Turkey enacted an "open door policy" and established refugee camps to house migrant populations (Koca 2016). Erdoğan's initial strategy was reflective of his belief the migrants would return to Syria upon conclusion of the war (Haugom 2019). After years of turmoil, and by 2016, Turkey expressed the need for assistance to support the ever-growing refugee population. Erdoğan compelled the EU through words and actions for help. An agreement was negotiated between the coalition and Erdoğan wherein "the EU offered Ankara 6 billion euros (\$7.1 billion) to help Syrian refugees and other incentives to prevent people from leaving Turkey to go to Europe" (Cook 2021).

Initially, "the agreement ... brought social benefits to Syrian ref- 
ugees in Turkey and their host communities, financial benefits to Turkey by alleviating its burden, and political benefits to EU politicians by reducing the flow of refugees" (Dempsey 2017). Since that time, however, President Erdoğan has endured a lengthier time of responsibility for the migrants and has chosen to take a strict position with the EU regarding the refugees. In 2020, the COVID-19 pandemic took hold, prompting Erdoğan to urge the Syrian population to move toward the border with Greece. This move proved manipulative on behalf of the Turkish government, with reporting by migrants they were told by the Turkish government that the Greek border would be open to them. Upon arrival, however, the Syrians were turned back by the Greeks and treated poorly (The Guardian 2020). Recent discussions between EU leaders and President Erdoğan have resulted in new agreements, despite vocal hesitation by many EU nations due to the manipulative and autocratic behavior of President Erdoğan.

\section{Literature Review}

\section{Introduction and Background}

$\mathrm{E}$ rdoğan is an intriguing political character for study and, while he has a great deal of supporters within the country of Turkey, he also has a large group of adversaries. Erdoğan is heavily motivated by his ideological beliefs in the Islamic faith. He is driven by his identification as a Muslim first, before he is Turkish. Many of his policies and support for nation stem from this association. His psychological drivers are ripe for assessment based upon the three theories noted above.

The republic of Turkey is a member of the North Atlantic Treaty Organization (NATO), yet has never been admitted to the European Union (BBC News, 2020). The President consistently establishes policies that are controversial, such as his expression of support for force against Bashar Assad and the Islamic State in Syria. In an interview with France 24, Erdoğan stated his frustration with comments made by the reporter regarding "Daish" being referred to as the Islamic State. President Erdoğan commented how it was unfair to refer to a terrorist organization as an Islamic State, since it is disrespectful to the religion of Islam. He further expressed a lack of support for Assad, and no confidence in him and his leadership. The President stated he believes in the right to life, and Assad has no respect for his people's rights to life (France 24, 2015).

Erdoğan has exhibited force against Kurds within Turkey and around the globe. Kurds make up approximately $20 \%$ of the population of Turkey, yet they are unable to qualify their existence since there is no "ethnic qualification" allowed in Turkey (Totten, 2015, 5). It is believed that the Turkish President fears Kurds within Turkey shall join with Kurds in Syria and stage an uprising within Turkey. Kurds have historically been tamped down in the nation, since the Ottoman Empire, and continue to be oppressed and silenced. The Turkish government does not allow the Kurdish language in schools and has 
moved populations of Kurds to remote parts of the country, causing a "cultural genocide" (Totten, 2015). Recent foreign policies include a long-standing feud with Greece regarding pipelines being run through the Turkish continental shelves, and maritime rights and air space in the Mediterranean with regard to oil stores (Aljazeerah, 2021). These policies are evident and explainable through a review of President Erdoğan's actions and the psychological drivers. Most concerning is the policy surrounding the Syrian refugee crisis. A review of the literature pertaining to the theoretical bases for these drivers and application to the subject will provide additional insight to conduct a predictive analysis to provide strategic guidance for policy recommendations.

\section{Psychological Constructivism}

Richard Ned Lebow, in his book, "A Cultural Theory of International Relations" examines the political actor through a lens of psychological and self-described as "open-ended" and "fundamental". He embraces motivations for action on the ever-changing momentum of society, and the need for actors to "push for change on the basis of reflection on their lives and the lessons of the past" (Lebow 2008, 506). His theory further develops the notion that individuals are not born into a set of goals and motives, but that those are developed within the political actor over time.

More specific drivers noted by Lebow include self-esteem, and basic human needs such as appetite, spirit, fear and reason. His concepts, rooted in
Greek philosophy, indicate these psychological drivers appeal to the emotional nature of individuals rather than the basic logic of a computer. He draws from real-world examples to identify these qualities in leaders and historical context to identify these psychological drivers at play (Lebow 2008).

In "The arrival of psychological constructivism," Jacques E.C. Hymans evaluates the theory of psychological constructivism further in terms of international behavior. The author challenges some of the works of Richard Ned Lebow and makes very valid points regarding the application of psychology in international relations and foreign policy. Hymans asserts the motivations for behaviors cannot be denied; "security, appetite, and self-esteem ... are exogenous to rational choice models" (Hymans, 2010, 462). Underlying drivers of basic human nature form our psychological beliefs and needs. Given these as truths, our inherent needs will inform how individuals deal with others, both within our own society and external through to other societies. The article continues to reflect in contradiction to Lebow's theory to reinforce states are rational in the assertion that states are not so. States are "hierarchical" groups formed of individuals; individuals who are driven by the motivating behaviors noted. Therefore, states are conglomerations of emotional, influenced creatures driven to act and enact policies based upon those motives. International actors, motivated by their basic human needs and emotion cannot, therefore, be rational. Those individuals cannot rightly identify why they do what they 
do; they simply do. This negates the Lebow theory of reason, in many ways. The needs identified such as security, appetite and self-esteem, will drive leaders to strive to ensure their constituents and citizens within their jurisdictions are guaranteed. Under this theory, those basic human needs will most certainly influence the policies enacted within domestic and international systems.

"Rethinking Democracy and International Peace: Perspectives from Political Psychology" evaluate another aspect of psychological constructivism as the works discussed above. Previous discussions regarding the perception of Authors, Hermann and Kegley, evaluate methods of national leaders and discuss how these heads of state perceive other democratic leaders may enact policies as they do if their values are similar. Due to this notion, these states will be less inclined to participate in "aggressive" foreign policy with those nations generally inclined to have similar values. Additionally, during extreme circumstances, those heads of state will be given more latitude as a result of their moderate and tolerant actions.

Hermann and Kegley provide additional insight in democratic identification through their description that these beliefs create a culture of identity that include ingroups and outgroups. The ingroups' perception of the outgroups involves "whether the other government is viewed as complying with the values and norms that fit the leader's conception of a "good group member," or whether the other leaders are perceived as permitting and con- doning behavior that is not faithful to "our community's" values and norms" (Hermann and Kegley, 1995, 519). If the authors are correct in this theory, and additionally apply the concept of Hyman's theory that nation states are formed of a hierarchy of individuals, these moral guides inherent to our being will then drive nations to form alliances with other states of similar beliefs.

Finally, David Patrick Houghton reviews social constructivism and its role within foreign policy analysis. A review of literature in this regard provides a similar framework as the perceptions noted above. His work states, in part, that when leaders view each other in peace and looking towards peace, the "major obstacle toward stable security cooperation [is] removed" (Houghton 2007, 29). When one perceives another comes in peace, a social construct has made peace possible, and it can be so. Houghton further discusses prior works on constructivism and the "structure/agency" problem. That is, a determination of the true value and effect a leader may have upon actual outcomes of policy and government. That dilemma exists within psychological constructivism, since these theories indicate policies written and enacted based upon perceptions, basic forces and instinct (Houghton 2007).

\section{Rational Actor Theory}

Further support for the underlying theory of psychological drivers influencing leaders and global actors are authors Monroe and Maher. In the article, "Psychology and Rational Actor Theory", the 
authors state that "[i]nsofar as we are cultural beings, the range of actions we even consider when making choices is quite constrained" (Monroe and Maher, 1995, 11). Within their discussion, they assert the proposition that humans are not inclined to make decisions based upon conscious choice; rather, their choices are determined based upon inherent cores. Their writing further dives in the evaluation of how moral values and the natural human basis of influences drives our decisions through a subconscious way. Choice is somewhat removed as a factor in the decision-making process, and basic nature takes hold. The theory then follows that there would be a lack of conscious decision-making processes (Monroe and Maher, 1995). The authors are not insinuating there is not thought involved, however, it indicates that our moral bases to which individuals are predisposed drive us to act a certain way. These ideals are, therefore, rational to us. The authors point to many different historical situations and contexts in which alliances and unions of nations formed by similar viewpoints and political policies may be identified. Preservation of moral values and ideologies are innate. The desire to protect those values drive individuals to those sharing a similar goal and viewpoint is inherent. Desires to strengthen one's position through alliances and joint efforts with others and many more like-minded individuals is indicative of the rational actor theory discussed herein.

On the other side of this coin exists a theory of rational actors that may be distinguished through an evaluation of opposing behaviors. In Mercer's article "Rationality and Psychology in International Politics", he reviews rationality and the application of political psychology to understanding biases and their effect upon the rational actor. Cognitive biases can and do exist within government. Mercer's reviews these biases and their application in policy development with the contention that "[a]nalysts must know what is rational before they can know what is not rational" (Mercer, 2005, 89). Mercer goes on to explain, as well, how despite a rational process to determine policy, it can still have an unfavorable outcome. This is due to the fact that application of rationality may produce a judgment, that judgment is based upon those factors that the individual renders rational based upon their own inherent codes and biases and, therefore, may still not meet the final objective and desired result (Mercer 2005).

\section{Social Identity Theory}

The concept of a social identity in psychology places a value on an individual through association with a group or category of individuals. Stets and Burke examine this process, through a comparison to identity theory, in "Identity Theory and Social Identity Theory". The authors assert that in evaluating oneself, by engaging in a process of self-classification, an individual may place oneself in a group or category, thereby forming an identity. This theory provides a return to the mentality of the ingroup, as being part of a social category will inject an individual into their perceived ingroup. Additionally, Stets and Burke 
indicate that, once associated with the group, individuals will most usually assimilate to the ways of the group, behave as others within the group, and differentiate him or herself from the outgroup.

The authors continue their discussion by distinguishing roles and identities within their groups. They note, specifically, how "[p]eople are tied organically to their groups through social identities; they are tied mechanically through their role identities within groups" (Stets and Burke, 2000, 228). An important aspect of social identity theory, according to these researchers, involves the depersonalization of the individual. The theory goes on to state that, once a social identity is created and activated by the individual, a resultant acceptance of the membership in the group and behavior with the group will occur. These behaviors are indicated through "group phenomena" such as group action, cooperation and cohesiveness (Stets and Burke 2000). These types of activities result in self-esteem, consistency and efficacy, a theme that has been underlying other theoretical discussion herein.

Christopher J. Devine takes social identity theory one step further in the development of the group mentality. "Ideological Social Identity: Psychological Attachment to Ideological in-Groups as a Political Phenomenon and a Behavioral Influence" investigates the role of ideology in political groups and association of the self. The author purports that ideology is a reliable and influential identifier of group designa- tion and behavior (Devine 2014). He reiterates the basic underlying tenet that individuals define themselves by the group in which they belong and that their basic desire for involvement and positive imagery will provide the basis for this group identification. These associations feed self-esteem and belonging, which psychologically motivates oneself to maintain the group's ideological standards and ideals through fulfillment of group activities. This theory is specifically applicable when discussing domestic and foreign policies, and individuals' adherence to an ideological group membership.

Alfred Evans goes one step further in evaluating ideology and its role in social identity theory, a concept central to the study of President Erdoğan. In "Ideological Change under Vladimir Putin in the Perspective of Social Identity Theory", Evans reflects upon Putin's conservative ideology at certain times of his political career, and significant changes that occurred during the course of his leadership. The author outlines certain types of "identity management strategies" that leaders use to augment national self-esteem (Evans 2015). Social mobility, social competition and social creativity may exist at different levels within the individual but will be employed in order to elevate the group and social identity to a new level when a negative identity exists. These three management strategies are crucial to the examination of President Erdoğan and are reviewed in more detail during the discussion of the leader. 


\section{Theoretical Framework}

To establish a basis for the argument and to justify suggested solutions to the research problem posed, several forms of research and review will be utilized. Much of the research performed and literature written pertain specifically to examination of psychological theories and their application to foreign policy theory and group and intergroup relationships. Much of the literature is contemporary and provides recent analyses of subjects adequately suited for comparison to the subject studied herein. A study of the theories noted above and application of factual circumstances of the subject's behaviors and actions will be reviewed comparatively. A determination of whether these psychological theories have relevance to Turkey's leader and, if so, whether they provide an insight into the driving forces behind his policies pertaining to the Syrian refugee crises. The discussion of these theories and the evaluation of the particular subject's actions and behaviors follows.

\section{Findings and Analysis}

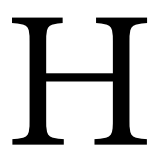

aving reviewed the theoretical bases for psychological evaluation within foreign policy, President Erdoğan can be studied within the framework established through that lens. Establishing a baseline of the personality and psychological drivers of the leader can provide a general understanding of his underlying motivational factors. "Personality traits affect an individual's motivation, goals, and values, thereby providing criteria to evaluate external stimuli" (Schoen, 2007, 412).

As previously discussed, Erdoğan is heavily motivated by his ideological religious beliefs, which is not surprising due to the origins of Turkey in the Ottoman Empire, which was a religiously based crusade movement and government. Therefore, much of his policies and support for nations stems from this association. Social identity theory provides a basis for this evaluation, in Erdoğan's association and his identification as Muslim and disassociation with other cultural groups within Turkey, such as the Turkish nationals and Kurds. Additional studies pertaining to culture where rivalries may exist within two nations are comparative and provide deeper context. Suedfeld and Jhangiani's study on India and Pakistan identify that, despite a shared history that extends centuries long, can still result in ingroups and outgroups and social identities that conflict (Suedfeld and Jhangiani, 2009).

A review of interviews and social media posts, as well as the leader's Biography on the nation's website presents the profile of a devote Muslim who speaks genuinely of his desire to support other Islamic nations and protect welfare and humanity. However, evidence has actually shown that Erdoğan has condemned people within Turkey for having differing views, and since the 2016 coup "more than 50,000 people have been detained, including many soldiers, journalists, lawyers, police officers, academics and Kurdish politicians" (BBC News, 2020). The leader's 
tolerance of condemnation of the outgroup, however, further confirms the behavior of the President to be in line with social identity theory's contention that an individual will support the group through behavior and activity in line with furthering the ingroup and to "stigmatize" the outgroup as much as possible (Evans 2015, 412).

As discussed earlier, psychological constructivism and rational actor theory hinge upon the actor's belief that he or she can solely impact policy and have an effect upon government. Leaning upon the writings of Fred I. Greenstein in "The Impact of Personality on Politics: An Attempt to Clear Away Underbrush", Erdoğan presents as an individual who believes he can likely impact policy and governmental actions on his own. Greenstein states, "the impact of an individual's actions varies with (1) the degree to which the actions take place in an environment which admits of restructuring (2) the location of the actor in that environment, and (3) the actor's peculiar strength or weaknesses" (Greenstein, 1967, 633-634). Political history confirms this exists for the leader in some way. Erdoğan secured, albeit marginally, a constitutional amendment necessary to effectuate a new form of presidency and democracy in the country. While many argue that this change was only to cement a longer rule over Turkey, the President was successful in garnering the support of his party and citizens of Turkey to vote favorably for the action. Greenstein's theory confirms Erdoğan's ability to bring some sort of modification and lasting change in an environment that admits to re- structuring, the location of Erdoğan in the government in the position of influence, and his own strength to influence his people to vote for the governmental structure change.

Additional evidence of the President's far-reaching influence includes the 2015 establishment of a Muslim party, the Parti Egalité Justice ("Equality and Justice Party"; PEJ), a network of European political parties developed the Turkish leader as an off shoot of his own party, the AKP. It is argued he established this network to provide influence throughout European nations and its Muslim population. This continued identification by the leader with his ideological group first, rather than a nationalist view, provides valuable context (Phil's Stock World 2017).

Psychological constructivism discussed by Hermann and Hagan further consider how leaders who tend to avoid conflict domestically may seek to accommodate foreign policy (Hermann and Hagan, 1998). Erdoğan is a leader who has demonstrated a tendency to welcome conflict on both fronts. This is evidenced by his consistent engagement in disputes with the EU, especially Greece and Germany, and domestically with the Kurds and the supporters of Gülen. Drawing from this evidence, it is supported that how leaders view themselves within the leadership realm is of the utmost importance to their identification of themselves and within the group. Erdoğan, while not narcissistic per se, has an unyielding confidence and portrays himself in that manner. He is, therefore, taken seriously and respected 
(or feared) as a global leader, despite the disagreement with many in the west and Middle East. In 2016, the leader took on the United Nation's Security Council by challenging the UN to reconstruct due to the lack of any Muslim country leaders on the council, adding that "Muslim countries should resolve their problems themselves" (Hafizoglu 2016).

Erdoğan's basic drivers, and underlying personality and leadership styles, were reviewed in a study performed in 2011, which identifies many of the obvious traits of the President. The authors, Görener and Ucal, correctly note that many times foreign policy is expressed without "any consideration of the individuals who occupy key government offices" (Görener and Ucal, 2011, 358). However, literature on political psychology has shown, this is not true. Hermann and Kegley discuss democratic identification, and how ingroups' perception of outgroups involves "whether the other government is viewed as complying with the values and norms that fit the leader's conception of a "good group member," or whether the other leaders are perceived as permitting and condoning behavior that is not faithful to "our community's" values and norms" (Hermann and Kegley, 1995, 519). Erdoğan's consistent association to his political part, based in ideological Islam and rooted in his basic needs to maintain that Muslim way of life drives his policies, both domestically and internationally.

Finally, as discussed above, President Erdoğan has long identified himself as a Muslim first, and Turkish second. Research further indicates how religious stability is desired by those who associate with an ideological basis, as that stability group identity of moral and ritualistic frameworks which are confirmed through historical constructs. This strong linkage to a religious group connects President Erdoğan in a way that reduces his ability to highlight those parts of his belief system and align to a nationalist belief. Erdoğan's consistent oppression of Kurds in the region, despite a 2013 speech in which the leader indicated "we are a government that has trampled on every kind of nationalism" provides confirmation of this argument (Butler, 2021).

Returning to the crisis at hand and subject of discussion herein, President Erdoğan is obviously a leader driven by his basic code as a Muslim; ideological and true to his ingroup, acting in line with theoretical bases inherent to support the group and distinguish it from outgroups that do not identity similarly. Self-esteem and basic human needs of security and spirit motivate this leader to act. The Syrian refugee crisis has plunged Turkey in a state of need and confusion. Millions of individuals have been living in the country for nearly a decade, with no end in sight. Negotiations and agreements with the EU to harbor these migrants provided immediate, yet temporary relief, and conditions cannot and have not been maintained to provide security and well-being for the migrant refugees or the Turkish. Additionally, the policy and international relations of Turkey with its bordering nations has suffered due to the prolonged nature of the crisis. 
In October 2019, the President launched a military objective against Kurdish forces in an effort to clear an area in northern Syria to allow for the resurgence of citizens into that region. Erdoğan believed that the establishment of a safe zone within the originating country would provide some relief for up to three million refugees. The offensive action resulted from failed further support by the EU, and the removal of troops by the US in the region that allowed the attacks to commence (Bathke 2019). Erdoğan's planned safe zone is imagined as depicted in Fig. 3 below.

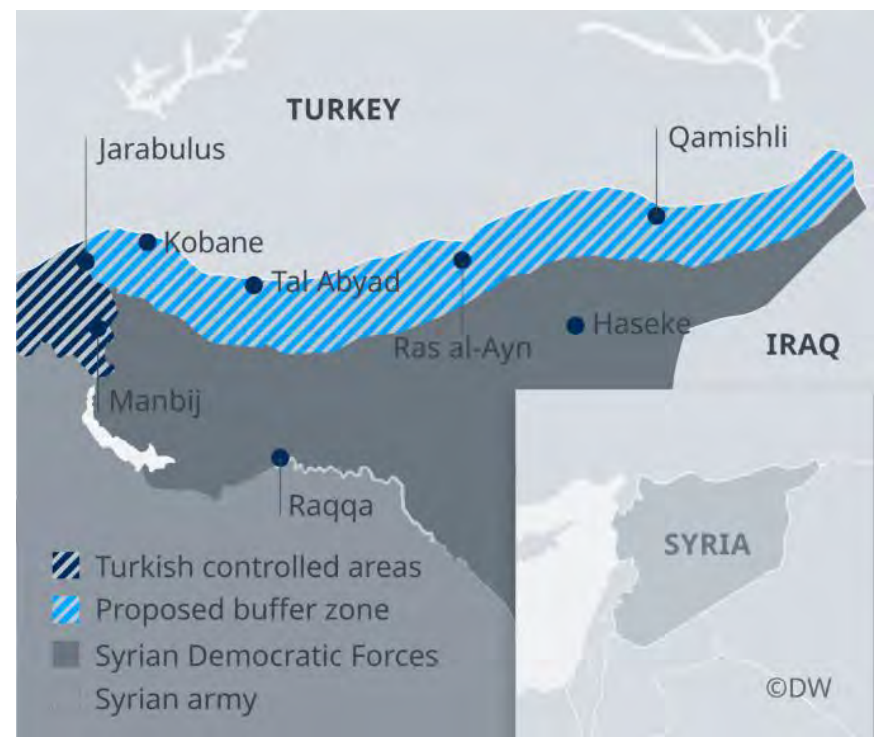

Fig. 3. Safe zone proposal. (Bathke 2019).

As the President's hopes for a safe zone failed to develop, and the COVID-19 pandemic took hold, in early 2020 , the leader began to threaten mobilization of migrants to the Greek border. By March of that year, buses of refugees were waiting at the entrance to Greece and met with resistance and cruel treatment. Backlash from Greece against the leader came quickly, throwing the countries into further disagreement. Again, in April 2021, "Greece accused Turkey on Friday of trying to provoke it by attempting to push boats carrying migrants into Greek waters, a claim Ankara strongly rejected" (Re- uters 2021). Greece insists witnesses viewed Turkish Coast Guard ships assisting the migrant vessels into Greek waters and warned the Turkish government to stand down on the practices. Greece called on Turkey to adhere to the previous agreement with the EU.

The question remains as to whether Syrian refugees will ever return to their native country even after the war concludes. A new deal with the EU does not seem forthcoming and Turkey, its citizenry and the migrants themselves have been thrust into a forced relationship of reliance and trust. Policies must be adjusted and approach to the leader 
conducted in a manner based upon an evaluation of the psychological factors discussed through the theoretical evaluation herein.

\section{Recommendations}

- Appeal to the leader's innate and inherent desire to protect his Muslim ideological bases. As indicated above, social identity theory contains a facet of ideological approach that drives individuals and, specifically, President Erdoğan. The evidence of his identification of himself as a Muslim in priority to Turkish nationalism provides a basis to leverage those ideals and ideological beliefs in establishing a policy to satisfy his need to protect the citizens of his country. Appealing to the leader's ideological beliefs, ensuring that policies proposed and agreed-upon protect these ideological bases and reassurance that the needs of the Muslim citizenry will be met will promote a policy with the President that may be more acceptable and enforceable in the future. Recognition of this priority within President Erdoğan shall provide greater applicability to the leader's social identity. Establishment of an agreement to support his citizenry, identifying the need to protect Islamic values and institutions first, may be key to successfully negotiating an agreement. Revisiting a safe zone and path to return Syrian refugees to their native land would play well into the Muslim leader's identification with another Muslim state's citizenry and desire to keep individuals with their ideological groups. Allowing these migrants into Europe would dispel the Islamic faith, however, through Europe, also reinforcing his identified desire to influence European culture and politics, as has been evidenced.

- Inherent and basic needs drive the rational actor to establish policy. While the Syrian refugees are also assumed to be Muslim, Erdoğan is also motivated to establish policies as a rational actor. As evidenced in research and literature regarding this theory, most do not recognize the forces underlying actions and behaviors. This theory provides the understand that preservation of moral values and basic needs must be foremost to the development of any policy. In line with the suggested course of action above, ensuring that financial, social and cultural needs are met is imperative to successful policy.

- Unidentified and other political factors may be at play. The readings indicated above prove that leaders do not always identify the reasons why they act, and for which the policies they enforce. The President is obviously concerned with the financial and cultural impact the refugees have taken upon his Turkish citizens and the country as a whole. Having negotiated a financial deal with the EU that provided monetary relief in support of the refugees 
has confirmed this assumption. It has failed in Erdoğan's eyes, however, or he is using the presence of these displaced individuals as chess pieces in order to manipulate the EU and other nations to provide other forms of political restitution for his harboring of these individuals. There are many underlying disagreements with the country of Greece that seem to have played into the President's recent attempts to flood the borders with migrants. A long-standing feud and failed attempts to rectify these issues due to the impacts upon other facets of the politician's psyche may be drivers to this activity. Further study and an exercise in evaluating further these policies and the political ramifications of a lack of further address is necessary.

\section{Conclusion}

$\mathrm{R}$ ecep Tayyip Erdoğan is a complex leader who is controversial and viewed by many on the global stage as one who will "push the limits" of domestic and foreign policy in order to make strides for his country. He has proven this through the early stages of his career which saw vast economic growth, as well as the 2018 passage of a constitutional amendment to allow ground-breaking political structural changes. His alliances seem born from identification as Muslim, rather than Turkish; a cultural and inherent core value instilled in him from upbringing. His nationalist identity is secondary to that of his ideological social identity, which drives him to support organizations such as the Muslim Brotherhood and Muslim nations outside of Turkey rather than the entire people that encompass his nation. These traits form the leader one that rules for some, but not for all, in a new democratic presidency that still does not seem quite democratic.

The study conducted herein has provided a basis to evaluate the leader's psychological code and forces that drive him to establish policies for his nation. When looking at the theories presented, psychological constructivism, rational actor theory and social identity theory, it is evident that President Erdoğan is a man that is not as complex as may originally be thought. His actions, words and policies speak volumes of his nature and the group with which he identifies most. His policies are protective of that group and his domestic and foreign policies display and nearly betray his allegiances in a predictable manner.

A man driven by basic needs and protective nature of his Muslim people, one who is ambitious and motivated to seek extension of his policies throughout Europe, can be addressed through those factors. As noted above, while the leader's attempts to join the EU may have been stunted, he has found other avenues to influence governments throughout the Union, by extending his party to other nations. Using the refuges within Turkey to negotiate financial dealings, and to threaten EU nations with a release of these people have brought attention and reaction to Turkey in a manner that may seem undip- 
lomatic to most; yet necessary to him, evident due to the threatening nature the influx of these individuals have had upon his society and culture. The review provided herein, and subsequent recommendations, may provide a basis for future dealings of a more informed and intuitive nature. Ever-changing political landscapes and societal and cultural concerns will influence the leader, however, as indicated in this review, basic ideological core codes and inherent needs will never change and, with that, a firm policy approach may be taken.

Janice Farkas is currently pursuing an applied doctorate in Strategic Intelligence and holds an MS in Legal Studies as well as a Graduate Certificate in Intelligence Management. Her primary area of research includes management and integration of law enforcement intelligence into the larger strategic intelligence enterprise. Highlights from her research include identifying the psychological motivators of global leaders, as well as strategies to further implement management changes to intelligence strategies. She welcomes opportunities for continued research and collaboration.

Casey Skvorc, PhD, JD is an Associate Professor in the doctoral programs of Strategic Intelligence and Global Security within the School of Global and Security Studies. As an attorney and medical psychologist, his professional experiences have included providing assessments of reliability and suitability for laboratorians conducting research in BSL-4 laboratories, providing assessments of dangerousness for high-risk federal prisoners considered for release from custody, as a recurring lecturer at the Federal Law Enforcement Training Center (FLETC) teaching Constitutional Law, and research participation in the U.S. Secret Service Exceptional Case Study Project. As the course professor for the Psychology of Global Actors course (SSGS 711), he guides doctoral students studying the application of psychological theories and constructs to enhance understanding of decision-making behaviors and actions of world political leaders.

\section{Bibliography}

Adely, Hannan. October 17, 2019. "Labeled terrorists in their homeland, hundreds of Turks are seeking asylum in New Jersey" NorthJersey.com. https://www.northjersey.com/story/news/new-jersey/2019/10/17/turkish-gulen-supporters-seekasylum-nj-after-post-coup-crackdown/3946510002/

Ahmad, Feroz. 1993. The Making of Modern Turkey. London: Routledge. 
Ahmad, Feroz. 2014. The Young Turks and the Ottoman Nationalities : Armenians, Greeks, Albanians, Jews, and Arabs, 1908-1918. Salt Lake City: University of Utah Press. Accessed April 24, 2021. ProQuest Ebook Central.

Aksakal, Mustafa. 2008. The Ottoman Road to War in 1914 : The Ottoman Empire and the First World War. Cambridge: Cambridge University Press. Accessed April 24, 2021. ProQuest Ebook Central.

Aljazeerah, March 17, 2020. Turkey's Erdoğan discusses Syria, refugees with European leaders. https://www.aljazeera.com/news/2020/3/17/turkeys-erdogan-discuss es-syria-refugees-with-european-leaders.

Aljazeerah, March 16, 2021. Greece, Turkey resume preliminary talks on Mediterranean dispute. https://www.aljazeera.com/news/2021/3/16/greece-turkey-resumepreliminary-talks-on-mediterranean-dispute

Bathke, Benjamin. October 10, 2019. “What's behind Erdogan's proposed 'safe zone' for Syrian refugees?" InfoMigrants https:/www.infomigrants.net/en/post/20083/ what-s-behind-erdogan-s-proposed-safe-zone-for-syrian-refugees

BBC News. October 27, 2020. Recep Tayyip Erdoğan: Turkey's pugnacious president. https://www.bbc.com/news/world-europe-13746679

BBC News. July 17, 2016. Turkey's coup attempt: What you need to know. https:// www.bbc.com/news/world-europe-36816045

BBC News. July 10, 2018. Turkey country profile. https://www.bbc.com/news/ world-europe-17988453

BBC News. February 28, 2020. Syria war: Turkey lets refugees exit towards Europe. https://www.bbc.com/news/world-europe-51678462

BBC News. October 27, 2020. Recep Tayyip Erdoğan: Turkey's pugnacious president. https://www.bbc.com/news/world-europe-13746679

Britannica, 2021. Ottoman Empire. https://www.britannica.com/place/OttomanEmpire

Butler,Daren.2021. Analysis:Movetoban KurdishpartyshowsErdogan'smarchtonationalism. Reuters. https://www.reuters.com/article/us-turkey-politics-kurds-erdo gan/analysis-move-to-ban-kurdish-party-shows-erdogans-march-to-national ism-idUSKBN2BB1CZ 
Cook, Lorne. March 25, 2021. EU offers Turkey aid, trade help despite rights concerns. Star Tribune. https://www.startribune.com/eu-offers-turkey-aid-tradehelp-despite-rights-concerns/600038358/?refresh=true

Davies, James C. 1963. "'You can't Change Human Nature'”' In Human Nature in Politics: The Dynamics of Political Behavior; Human Nature in Politics: The Dynamics of Political Behavior., 1-30, Chapter xi, 403 Pages. Hoboken: John Wiley \& Sons, Inc., John Wiley \& Sons Inc, Hoboken, NJ. doi:http://dx.doi.org.ezproxyl.apus. edu/10.1037/14301-001.

Dempsey, Judy 2017. "Is the EU-Turkey Refugee Deal on the Ropes?" Carnegie Europe. https://carnegieeurope.eu/strategiceurope/72634

Devine, Christopher J. 2015. "Ideological Social Identity: Psychological Attachment to Ideological in-Groups as a Political Phenomenon and a Behavioral Influence." Political Behavior 37 (3) (09): 509-535. doi:http://dx.doi.org.ezproxy1.apus. $\mathrm{edu} / 10.1007 / \mathrm{s} 11109-014-9280-6$. https://search-proquest-com.ezproxy1.apus.edu /scholarly-journals/ideological-social-identity-psychological/docview/170 $5946305 /$ se-2 ?accountid $=8289$.

Evans, Alfred. 2015. "Ideological Change under Vladimir Putin in the Perspective of Social Identity Theory" Demokratizatsiya: The Journal of Post-Soviet Democratization 23(4): 401-426.

Findley, Carter Vaughn. 2010. Turkey, Islam, Nationalism, and Modernity: A History. New Haven: Yale University Press. Accessed April 24, 2021. ProQuest Ebook Central.

France 24. March 27, 2015. Exclusive interview with Turkish president Recep Tayyip Erdoğan, https://www.youtube.com/watch?v=uBrmx8s_cpU

Görener, Aylin and Meltem Ucal, 2011. The Personality and Leadership Style of Recep Tayyip Erdoğan: Implications for Turkish Foreign Policy. Turkish Studies. Sept. 2011, 12:3, 357-381.

Greenstein, Fred I. Sep. 1967. "The Impact of Personality on Politics: An Attempt to Clear Away Underbrush" The American Political Science Review. 61:3 629-641.

Gülalp, Haldun. "Globalization and Political Islam: The Social Bases of Turkey's Welfare Party” International Journal of Middle East Studies. 33, No. 3 (2001): 433-448.

Hafizoglu, Rufiz. 2016. "Erdoğan: Muslim Countries should Resolve their Problems Themselves." Trend News.English, Apr 14. https://search-proquest-com. 
ezproxyl.apus.edu/wire-feeds/erdogan-muslim-countries-should-resolve-their/ docview/1784232012/se-2?accountid=8289.

Hermann, Margaret G. and Charles W. Kegley, Jr. 1995. "Rethinking Democracy and International Peace: Perspectives from Political Psychology". International Studies Quarterly. Dec. 1995, 39:4, 511-533.

Hymans, Jacques E.C. 2010. “The arrival of psychological constructivism." International Theory 2:3, 461-467. Doi: 10.1017/S17529719100000199.

Haugom, Lars. 2019 "Turkish Foreign Policy Under Erdogan: A Change in International Orientation?” Comparative Strategy 38, No. 3 (2019): 206-223.

Image, Treaty of Sèvres. Armenpress https://armenpress.am/eng/news/1024613. html.

Mays, Stephen (2017). Who is Recep Tayyip Erdoğan? USA News. https://www. usnews.com/news/best-countries/articles/2017-05-16/10-things-to-know-aboutrecep-tayyip-erdogan

Hermann, Margaret G. and Joe D. Hagan. 1998 "International Decision Making: Leadership Matters.” Foreign Policy. No. 110 (Spring): 124. Doi: 10.2307/1149281.

Hermann, Margaret G. and Charles W. Kegley, Jr. 1995. "Rethinking Democracy and International Peace: Perspectives from Political Psychology". International Studies Quarterly. Dec. 1995, 39:4, 511-533.

Houghton, David Patrick. 2007. "Reinvigorating the Study of Foreign Policy Decision Making: Toward a Constructivist Approach." Foreign Policy Analysis 3: 2445.

Kirisci, Kemal. March 17, 2021. As EU-Turkey migration agreement reaches the five-year mark, add a job creation element. Brookings. https://www.brookings.edu/ blog/order-from-chaos/2021/03/17/as-eu-turkey-migration-agreement-reachesthe-five-year-mark-add-a-job-creation-element/

Koca, Togral Burcu. May 2016. Syrian refugees in Turkey: from "guests" to "enemies"? New Perspectives on Turkey; Istanbul Vol. 54, (May 2016): 55-75. DOI:10.1017/npt.2016.4

Lebow, Richard Ned. A Cultural Theory of International Relations. Cambridge: Cambridge University Press, 2008. 
Mercer, Jonathan. 2005. "Rationality and Psychology in International Politics." International Organization. Winter, 2005, 59:1, 77-106.

Miller, Rebecca, M. December 17, 2014. “Time to Make Psychology a Part of International Relations". The National Interest. https://nationalinterest.org/feature/ time-make-psychology-part-international-relations-11872? page $=2$

Monroe, Kristen Renwick, and Kristen Hill Maher. "Psychology and Rational Actor Theory." Political Psychology 16, no. 1 (1995): 1-21. Accessed March 11, 2021. doi:10.2307/3791447.

Phil's Stock World: The "Islamization of Europe"? what's Behind Erdoğan's New Muslim Political Network 2017. Chatham: Newstex. https://search-proquest-com. ezproxy 1.apus.edu/blogs-podcasts-websites/phils-stock-world-islamization-eu rope-whats/docview/1908244625/se-2?accountid=8289.

Reuters Staff. April 2, 2021. "Greece accuses Turkey of trying to provoke it with migrant boats." https://www.reuters.com/article/uk-europe-migrants-greece-tur key/greece-accuses-turkey-of-trying-to-provoke-it-with-migrant-boats-idUSKB N2BP1IO

Schoen, Harald. 2007. Personality Traits and Foreign Policy Attitudes in German Public Opinion. The Journal of Conflict Resolution. June 2007: 51:3 408-430.

Shaw, Stanford J. History of the Ottoman Empire and Modern Turkey, Vol. 1. Cambridge: Cambridge University Press, 1976. https://hdl-handle-net.ezproxy2. apus.edu/2027/heb.01919. EPUB.

Stets, Jan E., and Peter J. Burke. "Identity Theory and Social Identity Theory." Social Psychology Quarterly 63, no. 3 (2000): 224-37. Accessed April 25, 2021. doi: $10.2307 / 2695870$.

Suedfeld, Peter and Jhangiani, Rajiv (2009). "Cognitive Management in an Enduring International Rivalry: The Case of India and Pakistan" Political Psychology. 30:6 937-950.

Totten, Michael J. 2015. “The Trouble with Turkey Erdoğan, ISIS and the Kurds” World Affairs. Vol. 178 Issue 3, p5-12. 8p.

Zürcher, Erik Jan (2019) The Young Turk revolution: comparisons and connections, Middle Eastern Studies, 55:4, 481-498, DOI: 10.1080/00263206.2019.1566124 